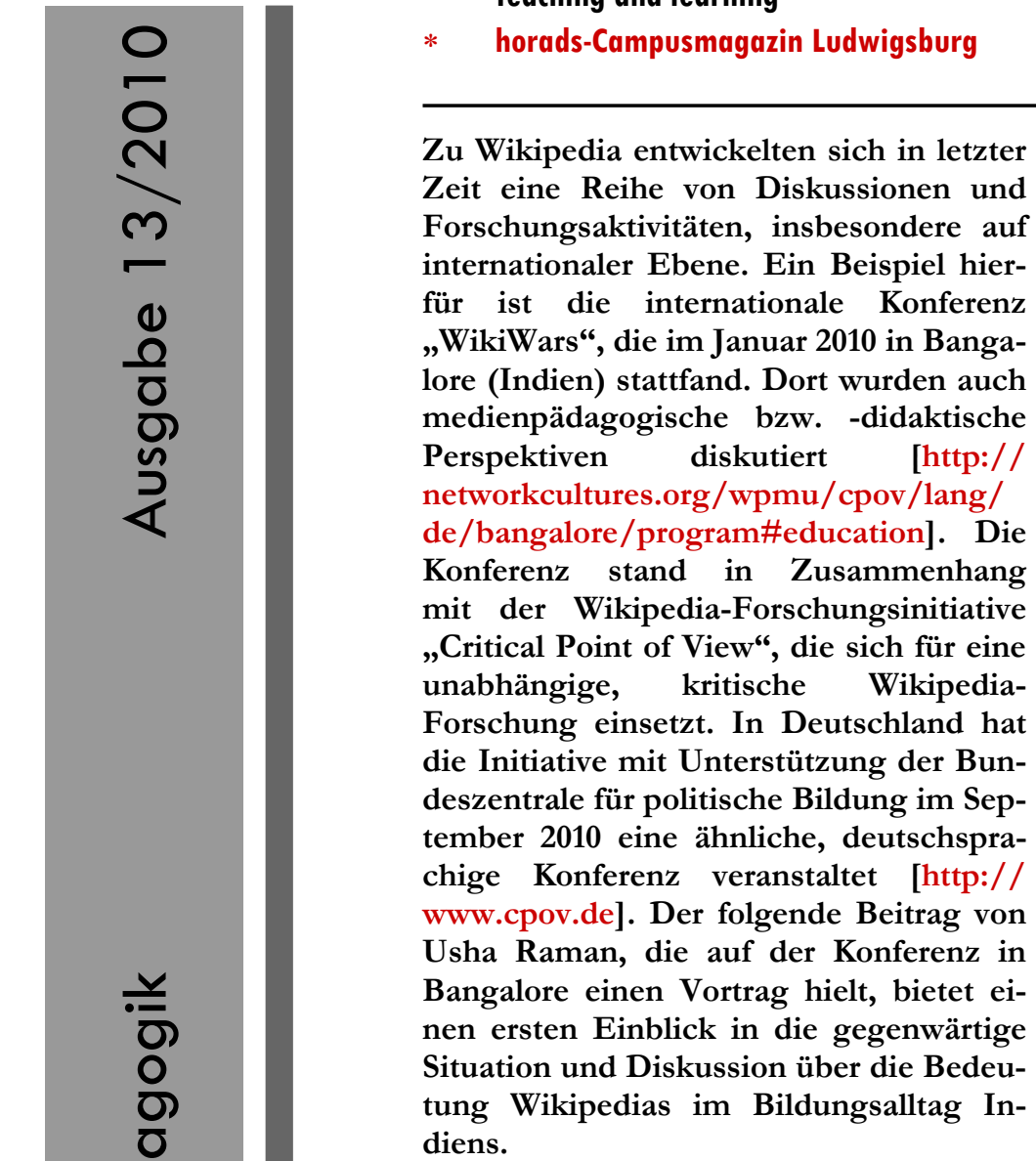

Die Redaktion

\section{The changing and changeable encyclopedia: Wikipedia and its implications for teaching and learning}

\section{USHA RAMAN}

\section{Introduction}

One of the big questions to confront teachers everywhere is how to handle the Internet when it comes to its use as a learning resource. In some ways this is a generational conundrum. The attitude to educational or information technology is structured and modified by experience as well as expectations of what, how and why one should learn, and what learning itself should constitute. It is structured by an idea of where learning happens, and what can contribute to it. The adoption and internalization of every innovation in the educational space must negotiate these expectations and perceptual frameworks. Web-based resources, both by virtue of the nature of the medium and by the structure of the texts themselves, introduce a discontinuity in the traditional modes of learning, and their ramifications are only beginning to be understood within educational spaces.

Among online learning resources, Wikipedia is one of the first points of information discovery when looking for material on the Web. While some academic institutions and instructors specifically prohibit using and referencing material from Wikipedia, younger learners, particularly at the primary and secondary levels, depend heavily on Wikipedia entries for a variety of purposes, from looking for information for projects to supplementing the textbook. What is lacking is a critical appreciation of the resource and an understanding of how it is built, that the information requires continuous validation, that users are also participants in the process of its creation. Clearly, such an understanding would lead to informed and more productive use of the resource, and also remove some of the distrust associated with Wiki information.

Such Web-based resources conceivably occupy different positions within different cultures of teaching/learning, and in different education systems. Where the culture of the classroom is open and critical, the Wikipedia and its attendant wiki forms are more likely to be more easily understood and adopted in the spirit of a resource that is not definitive but is subject to change, and importantly, is open to being questioned. In classrooms where learning is top down, text-book oriented and teacher-delivered, learning to use a resource that is itself a work in progress, inviting participation and contribution, poses a challenge and an opportunity. In this discussion paper I examine some of the issues thrown up by the use of dynamic resources such as Wikipedia in the average Indian classroom.

\section{Teaching and learning in Indian} classrooms

Most Indian teachers are products of a largely uni-directional and linear learning environment, dependent on poorly equipped or often non-existent libraries and the resources provided by their own instructors. 
Work, play, living and learning contexts were all separate and exclusive, each with different rules, sometimes driven by different values and a different set of expected outcomes. Their students, on the other hand, particularly those in urban middle class homes, have never known a world without digital technology, where access to information resources is vastly expanded, and where means to participate in dialogue and discussion is no more limited by geography or a host of other physical and material barriers. This is perhaps just one more facet of the divide in perception and experience between digital natives and digital migrants.

As happens with every generation, expectations of learning, teaching, the application of school work to life, and their relationships with the institutions they are a part of, are all moderated by their larger environment. This larger environment has been altered significantly in the past two decades and perhaps most significantly in the past decade, redefining the processes and the products of learning and more importantly, relationships with people and information.

Many teachers both at the school and university level have embraced new technologies enthusiastically, but this enthusiasm has in large part been fuelled by a largely uninformed (though not really unsubstantiated) hope that these tools will help make the teacher's job easier, make learning more fun and interesting, and will open access to learning resources that were hitherto denied most Indian children because of their cost or availability. Many others, however, continue to view technology as an intrusion, as something that unnecessarily adds to the list of things they need to be concerned about over and above the many tasks they need to attend to.

The classroom itself is a space that is tightly controlled and organized by the teacher, who is herself constrained by the strictures of the school and the board of education that she works within. In most classrooms, children sit in straight rows, their learning is organized into subjects and those subjects allocated specific time periods. Teaching and learning is parceled out into neat packages, with rare opportunities to transcend boundaries and mix ideas from two or more subjects together!

Further divisions happen in school life, as they do in life in general. There are times for play and for work, spaces where companionship and friendship can be played out and others where they must be suppressed. There are people who know and those who don't, people whose words are put into plastic sleeves and filed away and looked at and learned up, while others are dismissed or not allowed to speak.
Changes are happening, no doubt, but they are slow and for the most part restricted to a few privileged spaces. There is plenty of talk about student centeredness and open learning, but institutional structures are slow to accommodate this shift and even while policy makers pronounce reform, the shift is slow to express itself in the mood and mode of the classroom. Newer models of schooling, such as those influenced by international boards and directed by progressive educationists and parents who want "something different" for their children, are to be found in some of the larger cities, and also in alternative systems across the country, but these are still the minority.

\section{Enter collaborative learning tools}

Consequently, when new technologies and new paradigms of information consumption and production are introduced into these classrooms, two things (at least) happen:

1. The technology is fitted into traditional modes of doing, as simply one more layer of information

2. There is a process of negotiation that includes resistance and denial, and finally a recreation of the space as well as the process of learning.

The second process is what is of interest here. How does this process of negotiation happen and, specifically within the Indian culture of learning and teaching, how does it change the way learning and learning skills are acquired? What does it do to the traditional notions of learning and the directionality of the teacherstudent relationship?

Given the general discomfort most teachers feel toward such tools, the students are more likely to take over the learning process at least in those limited contexts where the use of such tools is encouraged. In such cases, even the act of using shifts some power to the student. Teachers then have to begin to look at their role differently, giving up some of their traditional power, accepting that knowledge creation and its reinforcement are participatory processes.

\section{Wikipedia: a "disruptive" educa- tional tool}

Wikipedia, which has grown into an important reference source for students at all levels, and is now increasingly seen as a valid source of information, is perhaps emblematic of the Internet as a resource. Apart from offering information per se, it also offers the opportunity - and the responsibility - to participate in knowledge generation, validation and extension, as well as ways to question and comment on material that has been through 
this process. Material, like the medium within which it is situated, is dynamic, changing, changeable and multi-authorial.

The location of such a resource within a space that has multiple uses, which collapses entertainment, relational and professional communication, as well as educational material also offers a variety of opportunities to see how learners negotiate conflicting and competing life and role demands and in the process make meaning not only of what they read but how they read, and how their process of reading also feeds into the re-creation of the text. It also offers a space and a moment that allows us to study the ways in which learning as an activity and an outcome is changing. Several educationists have noted the need to develop what some broadly call "network society skills" or "CCC literacies" critical, collaborative, creative literacies - that go beyond familiarity and ease of use of ICTs (Bruns and Humphreys 2005). To fully participate as not just consumers but as producers children need to acquire the ability to synthesize, assimilate and collaborate and engage in critical, reflective practices. Wikipedia, and similar collaborative knowledge repositories offer the spaces to develop such skills and engage in such practices.

\section{Critical literacy}

Teachers can use Wikipedia content to get students to look at gaps in "encyclopedic" entries. Encyclopedia are generally touted as standard references but the transparency of Wikipedia content (which offers frank notes when content is not substantiated or appears to be too promotional) provides learners with an opportunity to look at points of dissension, discussion, and consensus, so that the process of agreeing upon what is knowledge (which itself is temporary, transient, subject to change by users). Students could be encouraged to ask questions such as who originated an entry, who adds to it, which countries do most entries come from and what is the pattern of their finalisation, etc. Wikipedia, then imperfect as it may be as an objective information source, offers a perfect site for critiquing the imperfect and transient nature of all knowledge.

Collaborative literacy

Wikipedia allows online editing (although the edits must be approved by higher-level users) and therefore can be used for collaborative content creation. Augar et al. (2004) note that wikis promote peer interaction and facilitate the sharing of knowledge among learners. Gaps that are identified through a critical reading exercise or through serendipitous web surfing can then be filled in, by groups of learners acting in concert. Indian students may find that there is inadequate information on indigenous plants of India, and collect and collaboratively contribute an entry, putting together their complementary strengths in research, writing, and editing.

\section{Creative literacy}

Participation in knowledge creation calls for the ability to analyze and synthesize information and then put this understanding together in a manner that is comprehensible to someone else. The wide audience that is afforded by Wikipedia, opening up one's work to critique and criticism, and the opportunity to occupy a platform conjointly with other pieces of knowledge, all can be used to build a creative and responsible approach to content generation.

Apart from these opportunities for different kinds of "active" learning fostered by the Wikipedia in terms of its style of organization (as opposed to its content, primarily), directing children to using this resource also places them in a situation where they are likely to be distracted by the other attractions of the Net. Restricting one's field of view to a particular object of enquiry, developing the discipline to stay "on one window" while facing the attractions of chatting, gaming and random surfing online, and doing this while generating content for this same sphere, can all help build focus and concentration within an environment of distraction. In its positioning, Wikipedia mimicks life (as do other learning resources in an open online environment), therefore children are constantly learning within the constraints of constant distraction.

Currently a very small number of schools in India actively use Internet based tools within the classroom, although a large number of students have access to computers in their homes. Even though teachers actively discourage use of Wikipedia as a reference source, most students tend to use it liberally for projects and papers, and also to supplement material in textbooks. This is partly because well equipped libraries are difficult to come by; few schools have really rich library resources and public libraries as they exist in the West are practically non existent. The most obvious use of the Wikipedia therefore is as a simple information resource, one that itself draws from a variety of other sources, as any encyclopedia might. But to restrict its use to a simple unidimensional information source is to miss its larger potential for teaching and learning. Actively encouraging use of Wikipedia in student research calls for a certain critical engagement with the text. Students need to look at how this knowledge base is constructed, how its elements are argued over, discussed, and finally accepted or rejected, and 
- not by some external authority, but by users who are also "produsers" (Lister et al. 2003) of content, or knowledge.

Just as Web 2.0 tools have rendered the passive audience passé, Wikipedia and wiki forms in general encourage active participation in content generation rather than passive use although, in reality, a very small percentage of users actually get involved in creating or contributing content. This may change if learners, from a very young age, collaborate in meaning making and text-generation even when they are in school classrooms.

With Wikipedia introducing so many new dimensions into the way "texts" are viewed and used, individuals as members of this culture need to negotiate their relationship with learning and classroom power as they "naturalise" the use of such tools in their lives. Collaboration, discussion and the sharing of authority are qualities and practices that are not "natural" to the Indian learning context, except in very privileged institutions both at the secondary and tertiary levels. If students indeed discover the true use of the Wikipedia and are able to use such forms in order to learn from the learning process, they could become true participants in rather than mere recipients of products of the network society. What such a shift means to the politics of information and knowledge creation is another debate altogether.

\section{Literature}

Augar, N., Raitman, R. and Zhou, W. (2004): Teaching and learning online with wikis. http://www.ascilite.org.au/conferences/ perth04/procs/augar.html (accessed 12 December 2009)

Burns, A. and Humphreys, S. (2005): Wikis in teaching and assessment: The M/Cyclopedia Project. WikiSym '05, October 15 - 16, 2005, San Diego, CA, USA.

Lister, M., Dovey, J., Giddings, S., Grant, I. and Kelly, K. (2003): New Media: An Introduction. London: Routledge.

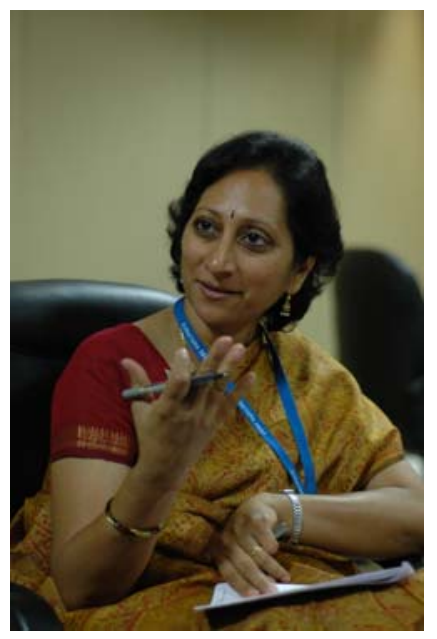

\section{Usha Raman, PhD}

Head, Communications, L V Prasad Eye Institute, Hyderabad

Usha Raman is a writer, editor and communications consultant based in Hyderabad, India, with a special interest in topics related to health, information technology, children's media and societies in transition. She holds a $\mathrm{PhD}$ in communication studies from the University of Georgia, Athens, GA, USA, where she also received her Master's in Journalism earlier. Her work has spanned helping health care organizations with internal and external communications processes and products and soft skills training for patient care staff, writing in the popular press on science, technology and health, and designing health campaigns. She is a visiting professor the University of Hyderabad, where she teaches courses on writing and science communication as part of the University's MA (Communication) programme. She also runs a professional monthly magazine for teachers, called Teacher Plus, and serves on the boards of two alternative schools that work with marginalized children. 


\section{horads - Campusmagazin Lud- wigsburg: „WIR SENDEN ZU- KUNFT !"}

horads - das Hochschulradio Stuttgart ist das Campusradio der Hochschulregion Stuttgart. Wir stellen Ihnen das Hochschulradio Stuttgart und das Campusmagazin Ludwigsburg vor.

\section{Holger Frank Heimsch \& MARIUS WIMMLER}

„Hallo und heralich Willkommen, hier ist wieder Euer Campusmagazin Ludwigsburg am Freitag Nachmittag". Mit diesem Satz begrüßen die Moderatoren ihre Hörerinnen und Hörer beim Campusmagazin Ludwigsburg von horads - dem Hochschulradio Stuttgart. horads das Hochschulradio Stuttgart bietet als Lernradio den Studierenden die Möglichkeit, das Medium Radio praxisnah kennenzulernen und das Programm von Studenten für Studenten und für alle, die sich für die Hochschulen in ihrer Region interessieren, zu produzieren.

horads hat nichts mit dem römischen Dichter Horaz zu tun. Seit dem 1. Januar 2004 kann man horads über die Hausantenne empfangen. Die Anfänge gehen aber auf ein Webradio zurück, das ab dem Jahre 1999 aus einem kleinen Produktionsstudio der Fakultät 3 für Information und Kommunikation der damaligen Hochschule für Bibliothek und Informationswesen (HBI) in Stuttgart sendete. Nach der Fusion der HBI und der Hochschule für Druck zur Hochschule der Medien im Jahre 2001 wurde am Standort Nobelstraße der Hochschule der Medien ein neues Studio in Betrieb genommen, das den kompletten Sendeablauf übernahm. 2005/2006 wurden zwei weitere Studios und Redaktionsräume errichtet, in denen die Wortredaktion eine neue Heimat fand. Nachdem die Redaktionsleitung und die Musikredaktion aus der Wolframstraße ebenfalls in die Nobelstraße umzogen, waren alle Redaktionen seit dem Sommersemester 2009 in der Hochschule der Medien beheimatet.

Das Hochschulradio Stuttgart finanziert sich durch den eigens gegründeten Trägerverein HochschulRadio Stuttgart (horads e.V.). Mitglieder von horads e.V. sind die Universität Stuttgart, die Hochschule der Medien Stuttgart, die Staatliche Hochschule für Musik und Darstellende Kunst Stuttgart, die Pädagogische Hochschule Ludwigsburg, die Hochschule für Verwaltung und Finanzen Ludwigsburg, die Evangelische Fachhochschule Ludwigsburg sowie der Paritätische Wohlfahrtsverband Baden-Württemberg. Ebenfalls wird horads finanziell unterstützt von der Landes- anstalt für Kommunikation (LfK) BadenWürttemberg.

Die Studierenden der verschiedenen Hochschulen bringen das jeweilige Know-how ihrer Fachrichtungen in den Sender mit ein und gestalten das Programm selbstständig. Einzelne Hochschulen haben ein zusätzliches Campusmagazin, beispielsweise die Pädagogische Hochschule Ludwigsburg.

Seit dem Sommersemester 2010 hat sich die neue Redaktion horads-Campusmagazin Ludwigsburg um die Redaktionsleiter Holger Frank Heimsch und Stefan Hundsdörfer versammelt und konzipiert und produziert Sendungen mit Themen von und mit den Hochschulen in Ludwigsburg. Zum Campusmagazin Ludwigsburg gehören die Pädagogische Hochschule Ludwigsburg, die Evangelische Hochschule Ludwigsburg und die Hochschule für öffentliche Verwaltung und Finanzen Ludwigsburg.

Zur Zeit besteht die Redaktion aus zehn festen Redaktionsmitgliedern und einer großen Anzahl an freien Mitarbeitern. Jeder Woche treffen sich die Redakteure zur Redaktionssitzung im neuen Redaktionsbüro im Medienzentrum der Pädagogischen Hochschule Ludwigsburg. Hier produzieren sie Beiträge, erstellen Sendelaufpläne und planen Themensendungen. Themen in der Sendung sind Veranstaltungen, Vorträge und Personen der Hochschule, Ereignisse in Ludwigsburg und allgemeine pädagogische und kulturelle Nachrichten.

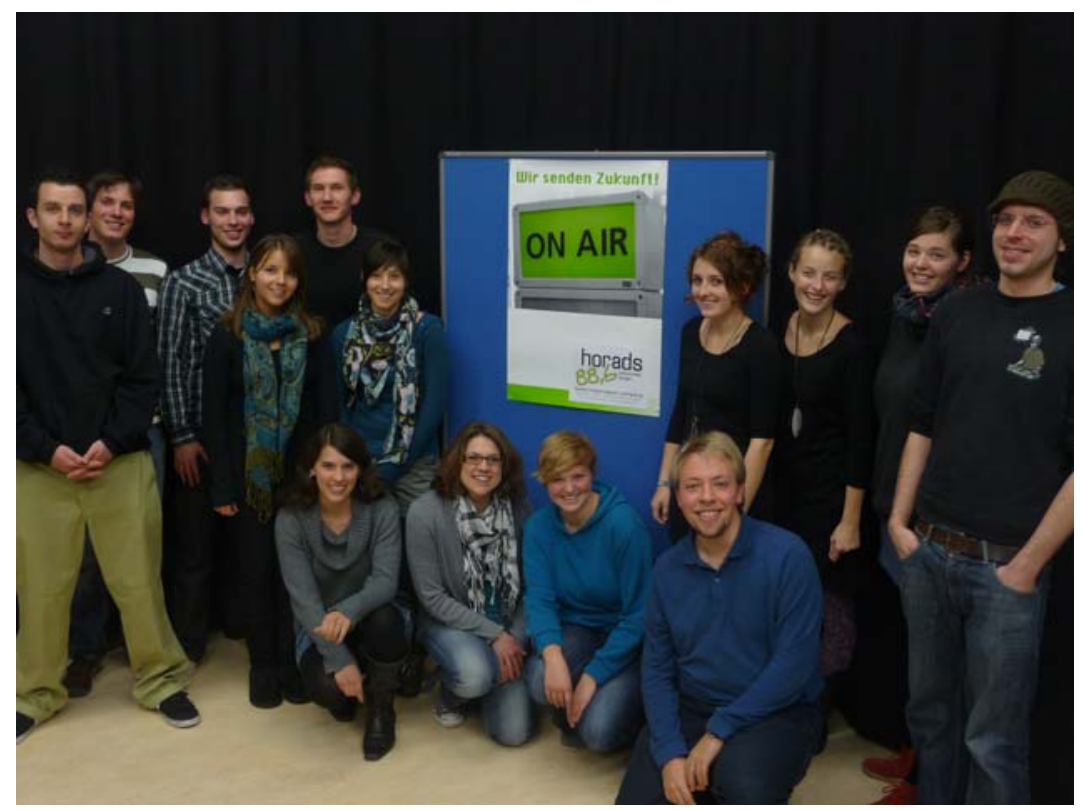

Themensendungen sind ein besonderes Highlight von horads-Campusmagazin Ludwigsburg. Eine Stunde über ein spezielles Thema, welches mit den Hochschulen in Ludwigsburg zu tun hat. Beispielsweise die Themensendung „Hinter dem Himmel schlafen die Märchen - ein Theater-, Kunst- und Mu-
Hier finden Sie einen Beitrag zum Sommerkonzert 2010 vom Hochschulorchester und Hochschulchor der PH Ludwigsburg. 
Hier kann man den Beitrag zur Umfrage „Was wünschst Du Dir für das neue Semester" vom 15.10.2010 und die Lubu-News vom 22. Oktober 2010 anhören. sikprojekt der PH“ (Juni 2010) oder „ZukunPHtsmusik mit der PH und einer ganzen Region“ (Oktober 2010).

In einer ganz normalen Sendung, welche wöchentlich gesendet wird, gibt es immer drei Themen, die Umfrage der Woche und die Lubu-News. horads-Campusmagazin Ludwigsburg kommt jeden Freitag Nachmittag zwischen 17 und 18 Uhr LIVE auf 88,6 oder als Livestream unter www.horads.de. Gesendet wird aus den Studios an der Hochschule der Medien in der Nobelstraße 10 in Stuttgart. Der Wunsch der Redaktion, LIVE aus Ludwigsburg zu senden, wird akribisch und mit viel Sorgfalt vorbereitet, damit es bald heißt: „Hallo und herzlich Willkeommen zum Campusmagazin Ludwigsburg, LIVE aus den Studios auf dem Campus der PH."

horads-Campusmagazin Ludwigsburg hat seit dem Wintersemester 2010/2011 ein neues Zuhause bekommen. Im umgebauten Medienzentrum an der Pädagogischen Hochschule Ludwigsburg teilt sich die Redaktion zusammen mit der Redaktion vom CampusTV „LuPHe“ einen großen Redaktionsraum mit vielen Computerarbeitsplätzen. Insgesamt stehen dem Radioteam vier Studios zur Verfügung.

In der Redaktion von horads-Campusmagazin Ludwigsburg können alle Studierenden der Pädagogischen Hochschule Ludwigsburg, der Hochschule für Verwaltung und Finanzen Ludwigsburg und der Evangelischen Hochschule Ludwigsburg aktiv mitmachen. Die Redakteure führen alle Interessierte in die journalistische Radioarbeit ein. Bei technischen Fragen und Produktionsproblemen steht mit Rat und Tat das Team des Medienzentrums der Pädagogischen Hochschule Ludwigsburg jedem zur Seite.

Wer sich im Bereich der Moderation oder Musikplanung fortbilden möchte, der kann in der Stammredaktion in Stuttgart eine achtwöchige Zusatzausbildung absolvieren. Hier bekommt er/sie in mehreren Lehrgängen und Sprechseminaren die Grundlagen eines Moderators bzw. eines Musikredakteurs vermittelt.

Das Team von horads-Campusmagazin Ludwigsburg freut sich über jede/n, der/die aktiv an der journalistischen Radioarbeit teilnehmen möchte. Jede/r ist zur Redaktionssitzung (montags, $12.45 \mathrm{Uhr}$ ) im Medienzentrum (Gebäude 4) der Pädagogischen Hochschule herzlich eingeladen.

horads-Campusmagazin Ludwigsburg berichtet auch von Ihrer Veranstaltung. Bei Fragen einfach eine Mail an campusludwigsburg@horads.de

\section{Alle Infos:}

horads-das Campusmagazin Ludwigsburg

Wer?

Mitmachen können alle Studierenden der PH, $\mathrm{EH}$ und HfVuF Ludwigsburg

Wann?

Freitags, 17-18 Uhr

Wo?

88,6 oder Livestream www.horads.de

\section{Redaktionssitzung?}

Montags, 12:45 Uhr Medienzentrum PH Ludwigsburg

\section{Redaktionsleitung}

Holger Frank Heimsch \& Stefan Hundsdörfer

Kontakt?

Mail: campus-ludwigsburg@horads.de

Web: www.ph-ludwigsburg.de/10205

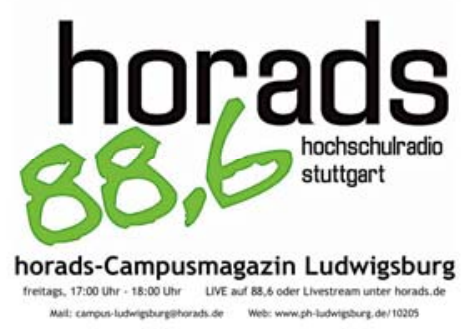




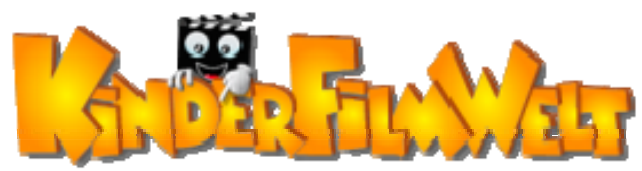

\section{Startschuss für Kinderfilm- welt.de. Das erste unabhängige Filmportal für Kinder in Deutschland ist online.}

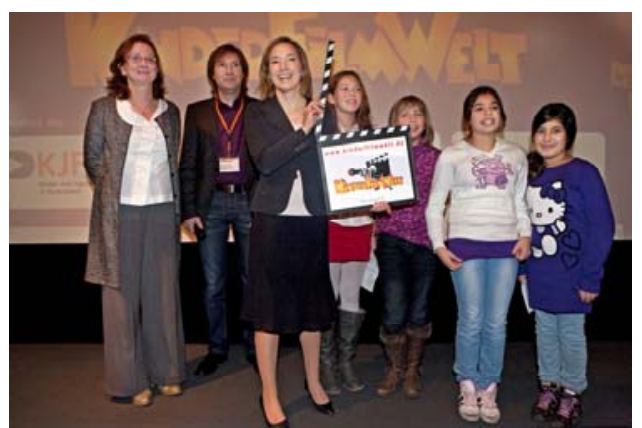

(Quelle: http://www.kinderfilmwelt.de/ index.php/de/presse/detail/items/das-ersteunabhaengige-filmportal-fuer-kinder-indeutschland-ist-online)

Am 29. November 2010 wurde der Startschuss für Kinderfilmwelt.de von der Bundesfamilienministerin Dr. Kristina Schröder im Kino Arsenal in Berlin gegeben. Kinderfilmwelt.de ist eine Informations- und Lernplattform, die sich an filminteressierte Kinder wendet. Entwickelt wurde das Portal vom Kinderund Jugendfilmzentrum in Deutschland (KJF).

Das Portal bietet Informationen zu aktuellen Filmen und DVDs, kindgerechte Rezensionen, Trailer und Altersempfehlungen. Neben den Kindern werden auch deren Eltern angesprochen, denen Tipps und Anregungen für die Medienerziehung gegeben werden.

Zur Pressemitteilung 